\title{
DO ESTADO AO INDIVÍDUO - REPENSANDO OS SUJEITOS DO DIREITO INTERNACIONAL PÚBLICO
}

\author{
Clarissa Franzoi Dri \\ Bacharel em Direito pela UFSM - RS. Mestranda em Direito pela UFSC. \\ e-mail: clarissadri@yahoo.com.br
}

RESUMO: O conceito de sujeito de direito é um dos elementos centrais dos ordenamentos jurídicos, na medida em que os contornos daquele determinam os pressupostos e os efeitos destes. Daí decorre a crucial importância de uma clara delimitação tanto dos atributos exigidos quanto das capacidades conferidas a quem possui personalidade jurídica em um dado sistema de normas. $O$ presente trabalho discute essa noção no âmbito internacional, a partir de uma análise dos sujeitos tradicionais do DIP (Direito Internacional Público) - Estados e organizações internacionais - e da ascensão do indivíduo neste cenário. Procura-se, assim, verificar se esses entes possuem as capacidades básicas dos sujeitos de direito - capacidade jurídica, capacidade de agir e direito de representação - mediante o estudo de suas possibilidades de atuação nos fóruns e tribunais internacionais, nos quais a pessoa humana é especialmente abordada. Ao final, delineiam-se as condições para o desenvolvimento e o aprimoramento dessa atuação, o que representaria um salto de qualidade e de efetividade no próprio direito internacional público.

PALAVRAS-CHAVE: Direito internacional público; Sujeito de direito; Indivíduo; Estado; Organização internacional. 


\section{INTRODUÇÃO}

Sabe-se que o conceito de sujeito de direito é convenção de um dado ordenamento jurídico. Seus contornos determinam, a partir de então, os pressupostos e os efeitos de tal ordenamento. Daí decorre a crucial importância de uma clara delimitação tanto dos atributos exigidos quanto das capacidades conferidas a quem possui personalidade jurídica em um Estado de Direito.

$\mathrm{Na}$ seara internacional, essa definição é igualmente relevante. Embora não disponha de poder centralizado, o DIP (direito internacional público) e suas características também dependem, em grande parte, de seus sujeitos. Ressalte-se que estes não se confundem com os atores das relações internacionais. ${ }^{1}$ Ator internacional possui conotação ampla e se refere a qualquer pessoa ou entidade que busque espaço ou possua voz no cenário internacional. Sujeito, por sua vez, é aquele que possui a titularidade de direitos e obrigações. ${ }^{2}$

Dentre estas faculdades, encontram-se duas essenciais: a capacidade de estar em juízo, ou seja, a capacidade de demandar perante um tribunal competente e, nos ordenamentos baseados no sistema representativo, o direito de elaborar as normas às quais se deve obediência. Nessa tripla perspectiva - capacidade jurídica, capacidade de agir e direito de representação -, procura-se analisar em que medida os Estados, as organizações internacionais e os indivíduos são sujeitos do direito internacional público.

A seguir, abordam-se as facetas e os limites da personalidade jurídica dos Estados e das organizações internacionais, pacificamente reconhecidos pela doutrina contemporânea como sujeitos do DIP (item 2), para depois tratar-se da complexa situação dos indivíduos no âmbito do direito internacional (item 3).

${ }^{1}$ Guido SOARES. Curso de Direito Internacional Público. v. 1. São Paulo: Atlas, 2002. p.141.

2 "Ser sujeito de Direito internacional não se confunde com a situação de ser destinatário de suas normas, nem com as entidades ou fenômenos que possam estar nelas mencionados, a título de proteção ou de evitar-se sua presença". Ibid., p.142. 


\section{A PERSONALIDADE JURÍDICA NA TRADIÇÃO INTERNACIONALISTA}

Os sujeitos do direito internacional público vêm mudando através dos tempos. Na Roma antiga, o direito das gentes dirigia-se mais aos indivíduos do que ao Estado, já que se destinava, notadamente, a regular a entrada e a permanência de estrangeiros em um dado território. No final da Idade Média, com o ressurgimento do comércio, a relevância do corpo político no plano internacional aumenta, consolidando-se na Idade Moderna o monopólio do Estado. No século XX, "o homem volta a ter direitos e deveres perante a ordem internacional. As organizações internacionais entram no campo jurídico como um dos principais e mais atuantes sujeitos de direito". ${ }^{3}$

Na ausência de determinação legal internacional acerca dos sujeitos do DIP, a doutrina contemporânea diverge. No entanto, a forte e longa tradição estatal (subitem 2.1) e o peso das organizações internacionais, formadas e dirigidas pelos Estados (subitem 2.2), impelem à ampla aceitação de sua personalidade jurídica.

\section{$1.1 \quad$ O Estado}

Os Estados são os sujeitos por excelência do direito internacional público. Eles ainda conformam, neste momento da história, o coração de tal sistema de normas, ${ }^{4}$ independentemente de sua organização interna. ${ }^{5}$ A soberania e a independência - ou interdependência - dos Estados continuam consistindo nos principais pressupostos do DIP.

Segundo Pierre-Marie Dupuys, as capacidades internacionais dos Estados estão divididas em cinco categorias fundamentais: a) capacidade de produzir atos jurídicos internacionais; b) capacidade de verem-se imputados fatos ilícitos internacionais; c) capacidade de acesso aos procedimentos contenciosos internacionais (diplomáticos ou jurisdicionais); d) capacidade de tornarem-se

${ }^{3}$ Celso de Albuquerque MELLO. Curso de Direito Internacional Público. 9. ed. rev. e aum. Rio de Janeiro: Renovar, 1992. p.279. 1994. p.39.

${ }^{4}$ Rosalyn HIGGINS. Problems \& Process: international law and how to use it. Oxford: Clarendon Press,

5 Como os Estados organizam-se internamente é assunto que escapa ao Direito Internacional, constituindo-se matéria de ciência política e pertencendo, portanto, ao denominado "domínio reservado dos Estados". Guido SOARES, op. cit. (nota 2), p.145. 
membros e de participarem plenamente da vida das organizações internacionais intergovernamentais; e) capacidade de estabelecer relações diplomáticas com outros Estados. ${ }^{6}$ Uma outra capacidade, segundo Guido Soares, seria a de "exercer, frente a outros Estados, efetiva e legítima proteção a pessoas físicas e jurídicas que os Estados consideram como seus nacionais"”. Essa noção de cidadania é própria dos Estados-nação, inexistindo nas organizações internacionais, nas quais a relação com seu capital humano ocorre mediante o vínculo funcional.

De outra banda, entre os deveres internacionais dos Estados encontram-se: a) não-ingerência nos negócios internos de outros Estados; b) estabelecimento de restrições a atividades que importam utilização imoderada dos respectivos territórios; e c) exercício da competência sobre pessoas e bens sob sua jurisdição. ${ }^{8}$

O principal sujeito do DIP deve reunir três elementos indispensáveis: população, território, mesmo se questionado, e governo efetivo, estável e soberano. ${ }^{9}$ A população, como conjunto das pessoas que habitam um Estado, não se confunde com o povo, formado pelos cidadãos, natos ou naturalizados, habitantes ou não do Estado do qual são nacionais. Estes detêm capacidade de participar das decisões políticas, enquanto o conceito de população vincula-se a um caráter demográfico, podendo incluir estrangeiros. ${ }^{10} \mathrm{~A}$ nacionalidade, portanto, consiste em um vínculo

\footnotetext{
${ }^{6}$ Apud ibid., p.147-150.

7 lbid, p. 150.
}

${ }^{8}$ Ibid., p.146. Mello entende que, à semelhança dos indivíduos, os Estados possuiriam direitos naturais e inatos, pelo simples fato de existirem. Op. cit. (nota 3), p.355. Nesse sentido, a Carta da Organização dos Estados Americanos (OEA), em seu capítulo IV, dispõe que são direitos e deveres fundamentais dos Estados a igualdade jurídica (art. 9º), a existência política independente do reconhecimento (art. 12), o direito de proteger e desenvolver a sua existência (art. 14), o direito de exercer a jurisdição no seu território (art. 15), o direito ao desenvolvimento cultural, político e econômico (art. 16), a inviolabilidade do território (art. 20) e a legítima defesa (art. 21).

${ }^{9}$ Convenção Pan-americana sobre Deveres e Direitos dos Estados, assinada em Montevidéu em 1933 e incorporada ao ordenamento brasileiro por meio do Decreto 1.570/37, estabelece que o Estado, como pessoa de Direito Internacional, deve reunir os seguintes requisitos: a) população permanente; b) território determinado; c) Governo; e d) capacidade de entrar em relações com os demais Estados. Este último requisito, contudo, parece mais conseqüência da condição de Estado do que seu elemento constitutivo, caso se considere o reconhecimento como ato não constitutivo, mas declaratório da personalidade internacional do Estado. Weber, por sua vez, ressaltando a presença do Direito, entende que o Estado moderno se caracteriza por: a) ser uma ordem administrativa e jurídica; b) ser um aparato administrativo que é regulamentado por uma legislação; c) ter autoridade legal sobre as pessoas e atos praticados no seu território; d) possuir legitimidade no uso da força. Apud ibid, p.291.

${ }^{10}$ Paulo BONAVIDES. Ciência Política. 10. ed. São Paulo: Malheiros, 1999. p.68 e 75. 
político entre o Estado e o indivíduo, sendo este um membro da comunidade constitutiva da dimensão pessoal do Estado. ${ }^{11}$

O território, a seu turno, é o limite material da jurisdição do Estado, e compreende o território terrestre, o espaço aéreo sobrejacente e o mar territorial. ${ }^{12} \mathrm{O}$ princípio da territorialidade indica que todo sujeito de direito, uma vez encontrandose num dado território, deve respeitar as leis que ali estão em vigor. Embora existam exceções em matéria penal ou fiscal, o que confere relatividade ao princípio, não se admite a extraterritorialidade, devido aos princípios da não-intervenção e da igualdade jurídica entre os Estados. ${ }^{13}$

A soberania surge com o Estado moderno, que se sustenta com 0 nascimento das teorias absolutistas e em um cenário de urgente concentração de poder. ${ }^{14}$ Mesmo significando, inicialmente, um poder absoluto e perpétuo, ela deveria ter acima de si o direito natural e o direito das gentes. ${ }^{15}$ Com efeito, embora seja una e indivisível, evitar a flexibilização do caráter absoluto da soberania seria negar o próprio direito internacional público. Assim, "Estado soberano é aquele que não se encontra numa situação de dependência, jurídica ou geral, em relação a outro Estado". ${ }^{16}$

Algumas classificações do termo o dividem em soberania interna, representando o monopólio da coerção legítima em certo território, e externa, que configura uma reivindicação de universalidade limitada a certo espaço geográfico. ${ }^{17}$ A soberania nacional, por sua vez, resultou do processo de afirmação do Estado

11 José Francisco REZEK. Direito Internacional Público: curso elementar 2. ed. São Paulo: Saraiva, 1991. p.180.

12 Ricardo SEITENFUS e Deisy VENTURA. Introdução ao Direito Internacional Público. 3. ed. rev. e amp. Porto Alegre: Livraria do Advogado, 2003. p. 69. Segundo aos autores, a jurisdição é o "exercício geral das competências atribuídas pela Constituição às instituições nacionais, que compreendem as funções de legislação, gestão e administração da justiça". p. 73. Em sentido estrito, "a jurisdição constitui o poder-dever de declarar a lei que incidiu sobre o caso concreto e aplicá-la coativa e intencionalmente." Athos Gusmão CARNEIRO apud ibid., p.74.

\footnotetext{
13 Ibid., p.74.
}

14 lbid., p.62.

${ }^{15}$ Celso de Albuquerque MELLO, op. cit. (nota 3), p.293.

${ }^{16}$ Ricardo SEITENFUS e Deisy VENTURA, op. cit. (nota 12), p.64. Os autores colocam ainda que as características da soberania são as competências - poder de ordenar todos os poderes do Estado - e a supremacia - inexistência de qualquer esfera de poder acima do Estado em território nacional.

17 Luis WECKMANN apud ibid., p.63. 
moderno, enquanto a soberania popular relaciona-se com a afirmação do princípio representativo.

Se o direito internacional enseja uma relativização da soberania, a supranacionalidade a limita fortemente. ${ }^{18}$ Nas organizações supranacionais, os Estados-membros submetem-se a um poder que lhes é superior e representa a coletividade. Já nas organizações meramente intergovernamentais, não há limitação de soberania e os interesses individuais tendem a predominar.

Presentes estes três elementos em uma organização política - população, território e governo soberano -, ela pode ser reconhecida pela comunidade internacional como um Estado. Passa-se, a seguir, à análise do conceito e das características das organizações internacionais, com o fito de compreender os alcances de sua personalidade jurídica no plano internacional.

\subsection{As organizações internacionais}

"As organizações internacionais são associações voluntárias de Estados, constituídas através de um tratado, com a finalidade de buscar interesses comuns por intermédio de uma permanente cooperação entre seus membros". ${ }^{19}$ Elas diferem das organizações não-governamentais, que são criadas por particulares associados e ganharam espaço na cena internacional somente após 1960. Também não se confundem com os Estados, por óbvio. Estes apresentam desigualdades quantitativas entre si, mas são iguais qualitativamente. Já as organizações internacionais mostram desigualdades quantitativas e qualitativas, sobretudo. ${ }^{20}$

A doutrina não adota uma tipologia unânime com relação às características destas entidades. Para Fischer Williams, os caracteres clássicos de uma organização internacional são capacidade de contratar, capacidade de ingressar em juízo e de ser processada, capacidade de possuir propriedade e uma vontade distinta, ou seja, decisões que ultrapassem ou mesmo difiram dos desejos de todos

${ }^{18}$ Supranacionalidade é um poder, real, autônomo, colocado a serviço de objetivos comuns a diversos Estados. Pierre PESCATORE apud ibid., p.69.

${ }^{19}$ Deisy VENTURA e Ricardo SEITENFUS, op. cit. (nota 12), p.88.

20 José Francisco REZEK, op. cit. (nota 11), p.249. 
os Estados-membros. ${ }^{21}$ Guido Soares, por sua vez, afirma que tais organizações devem ser instituídas mediante um tratado ou uma convenção internacional, possuir poderes decisórios que não dependam da vontade de nenhum Estado em particular e ser regidas pelo DIP, não pelo direito nacional de algum Estado. ${ }^{22}$ Já para Deisy Ventura e Ricardo Seitenfus, as principais características das organizações internacionais são a multilateralidade - regionalismo ou universalismo -, a permanência - elas possuem duração indefinida, secretariado com sede fixa e personalidade jurídica internacional - e a institucionalização - baseada na previsibilidade, na soberania e na voluntariedade. ${ }^{23}$

Quanto às competências, estas guardam estreita relação com os objetivos da organização. De modo geral, elas dividem-se em competências deliberativas, normativas, operacionais, de controle e impositivas. ${ }^{24}$ Para desempenhá-las, a entidade conta com dois órgãos fundamentais: a assembléia geral, que reúne periodicamente, para a tomada de decisão, ${ }^{25}$ os representantes dos Estadosmembros, e a secretaria, que executa tarefas administrativas com funcionários contratados. Nas organizações de caráter essencialmente político, existe também um conselho permanente, a exemplo do Conselho de Segurança das Nações Unidas.

A exemplo dos Estados, as organizações internacionais são amplamente reconhecidas como sujeitos do DIP, qualidade que deriva de suas competências, ao invés de constituir-se em fonte delas. Esta definição funcional da personalidade jurídica internacional foi estabelecida pela CIJ (Corte Internacional de Justiça):

\footnotetext{
${ }^{21}$ Apud Rosalyn HIGGINS, op. cit. (nota 4), p.46.

22 Op. cit. (nota 1), p.152-154.

${ }^{23}$ Op. cit. (nota 12), p.86.

24 Ibid., p. 92.

${ }^{25}$ Diferentemente do direito interno, o direito internacional não possui meios de obrigar a minoria a acatar a decisão da maioria no processo decisório de uma organização internacional. Mas a entidade pode estabelecer sanções, que em geral consistem na suspensão de determinados direitos e na exclusão dos
} discordantes do quadro de membros. 
trata-se da capacidade de ser titular de direitos e obrigações internacionais, dependendo esses direitos e obrigações dos objetivos e funções atribuídos à organização, sejam eles enunciados ou implicados por seu ato constitutivo ou desenvolvidos na prática. ${ }^{26}$

Assim, ao mesmo tempo em que as organizações têm personalidade jurídica objetiva, independente de reconhecimento de Estados, ela vincula-se a suas finalidades e competências, não bastando que uma organização declare que possui personalidade jurídica internacional para efetivamente possuí-la. ${ }^{27}$

Por outro lado, esse caráter das organizações é limitado se comparado à personalidade jurídica conferida aos Estados. No caso de divergência entre um Estado e uma organização internacional, por exemplo, a ClJ limita-se a emitir pareceres consultivos, já que uma organização não pode configurar pólo passivo ou ativo em procedimentos que envolvam Estados. ${ }^{28}$ Ademais, a Corte estabeleceu que é preciso cumprir três requisitos para a solicitação de um parecer: o organismo deve estar devidamente autorizado, em virtude de sua carta constituinte, a solicitar opiniões da Corte; a opinião solicitada deve se referir a uma questão jurídica; e essa questão deve surgir dentro da esfera de competência do organismo solicitante. ${ }^{29}$

Dessa forma, resta claro que as organizações intergovernamentais são sujeitos de direito internacional público, mas não têm os mesmos poderes e não

${ }^{26}$ Parecer Consultivo sobre Reparação de Danos Sofridos a Serviço das Nações Unidas, ou caso Bernardotte, de 11/04/1949, submetido pela Assembléia Geral da Organização das Nações Unidas (ONU). Disponível em: <http://www.icj-cij.org/cijwww/cdecisions/csummaries/cisunsommaire490411.htm>. Acesso em: 10 abr. 2005.

27 A UE (União Européia), por exemplo, possui personalidade jurídica internacional, embora nenhum tratado tenha disposto nesse sentido (hoje, tal preceito encontra-se consubstanciado no artigo 6을 do Tratado que Estabelece uma Constituição para a Europa). Essa personalidade compreende a capacidade de representação, o direito de estar em juízo (responsabilidade internacional), a capacidade de negociar e concluir acordos internacionais, a capacidade de participar dos trabalhos das organizações internacionais e de tornar-se membro. Denys SIMON, Le système juridique communautaire. 3. ed. Paris: Presses Universitaires de France, 2001. p. 119-120. O autor também coloca que "esta 'afirmação da personalidade internacional das Comunidades Européias' objetiva traduzir na esfera das relações internacionais o 'caráter unitário' da construção comunitária. Ela reflete a unidade interna da ordem constitucional comunitária e a expressa a 'identidade' da União.” p.121. Com relação ao MERCOSUL, somente o Protocolo de Ouro Preto estabeleceu que o bloco é dotado de personalidade jurídica internacional (art. 34), frente ao silêncio do Tratado de Assunção sobre o assunto. No entanto, é difícil afirmar que antes de 1995 a entidade não fosse sujeito do DIP, haja vista os tratados celebrados. Havia o que se pode chamar de "personalidade jurídica embrionária". Deisy VENTURA. As assimetrias entre o MERCOSUL e a União Européia: os desafios de uma associação inter-regional. Barueri: Manole, 2003. p.72.

${ }^{28}$ Decisão constante do parecer do caso Bernardotte. Cf. nota 36.

29 Parecer da ClJ no caso da legalidade do uso, pelos Estados, de armas nucleares em conflitos armados, proposto pela OMS (Organização Mundial de Saúde) em 1993. Disponível em: <http://www.icjcij.org/cijwww/ccases/canw/canwframe.htm>. Acesso em: 10 abr. 2005. Tais requisitos parecem ter sido lamentavelmente estabelecidos para que a Corte tivesse meios de evitar posicionar-se nas delicadas questões propostas pela OMS. 
gozam da plenitude dos direitos e deveres atribuídos aos Estados, tendo em vista que as normas do DIP tratam-nos de maneira substancialmente diferenciada. ${ }^{30}$ Situação similar ocorre com a pessoa humana, conforme se passará a verificar.

\section{O INDIVÍDUO COMO SUJEITO DO DIP}

Se a qualificação dos Estados e das organizações internacionais como sujeitos do DIP é pacífica doutrinariamente, o mesmo não ocorre com o indivíduo. Embora a personalidade internacional da pessoa humana tenha sido reconhecida por precursores do direito das gentes, ${ }^{31}$ a doutrina internacionalista inclina-se a não admitir tal característica ou a fazê-lo com severas restrições.

A compreensão das capacidades internacionais desses entes é determinante nas diferentes classificações acerca dos sujeitos do direito internacional. Portanto, parece imprescindível um estudo da possibilidade de gozo das faculdades dos sujeitos - direito de representação, capacidade jurídica (subitem 3.1) e capacidade de agir (subitem 3.2) - pelo indivíduo no plano internacional.

\subsection{Limites e lacunas de uma personalidade jurídica}

Rosalyn Higgins entende que o não-reconhecimento do indivíduo como sujeito de direito internacional público encontra guarida na arcaica e inútil divisão entre sujeitos e objetos do direito e na compreensão de que se algo é ou sempre foi de uma determinada maneira, deve continuar dessa forma. Para a autora, não se deve falar em sujeitos e objetos, mas em partícipes. Estes, no DIP, seriam tanto Estados como organizações internacionais, empresas multinacionais, grupos não-governamentais privados e indivíduos. ${ }^{32}$ Ora, em sendo o direito uma proporção entre coisas e pessoas, do homem e para o homem, ${ }^{33}$ é inconcebível a noção da pessoa humana

${ }^{30}$ Guido SOARES, op. cit. (nota 1), p. 143.

31 Francisco de Vitória, em 1532, já escrevia que entidades não-estatais deveriam ter direitos internacionais reconhecidos. Rosalyn HIGGINS, op. cit (nota 4), p.49. Hugo Grotius (1625) também considerava que os Estados e os indivíduos são pessoas internacionais. Essa compreensão insere-se, por exemplo, na afirmativa de que o compromisso de particulares perante inimigos de guerra obriga o Estado. O Direito da Guerra e da Paz. v. 2. Ijuí: UNIJUí, 2004. p.1457.

32 Rosalyn HIGGINS, op. cit. (nota 4), p. 49-50.

33 Dante ALIGHIERI apud Guido SOARES, op. cit. (nota 1), p. 156. 
como objeto do direito. Mesmo assim, ela ainda não é, hoje, sujeito pleno do DIP, por não lhe serem concedidas todas as faculdades inerentes a esses entes.

O indivíduo, com efeito, não se envolve na produção do acervo normativo internacional. Essa tarefa é desempenhada pelos Estados e pelas organizações internacionais. Embora, em tese, os governos devam representar os interesses de suas populações, parece difícil constatar um direito de representação nos moldes nacionais. Ao mesmo tempo, soa inconcebível esse direito do indivíduo no plano internacional, dada a impossibilidade material dessa representação. As ONGs (organizações não-governamentais), contudo, caso fossem dotadas das mesmas prerrogativas dos sujeitos do DIP, poderiam contribuir para a elaboração de normas mais legítimas e minimamente próximas de interesses temáticos das populações.

Com relação à titularidade de direitos e obrigações, sabe-se que o homem goza de direitos primordiais e inatos na ordem internacional, tais como liberdade individual, salvaguarda da saúde e da vida, proteção dos frutos do trabalho intelectual e industrial, garantia de condições de trabalho eqüitativas e proteção das minorias. ${ }^{34}$ A Declaração Universal dos Direitos do Homem, de 1948, e diversos outros documentos internacionais posteriores visam tutelar 0 indivíduo. Similarmente, este possui também deveres, dentre os quais está a possibilidade de ser julgado internacionalmente como criminoso de guerra ${ }^{35}$ ou por outros crimes, pelo TPI (Tribunal Penal Internacional). ${ }^{36}$

Mesmo verificando-se a capacidade jurídica internacional da pessoa humana, sua personalidade não é completa. Além de não participar da produção das normas internacionais, o indivíduo praticamente não possui capacidade de agir, isto é, não realiza atos válidos no plano internacional. Mais do que a titularidade de direitos e deveres, para que houvesse a plenitude de sua personalidade jurídica ele

34 Hildebrando ACCIOLY. Manual de Direito Internacional Público. 11. ed. rev. São Paulo: Saraiva, 1978. p.175. Ratifica a afirmação o fato de existir responsabilidade internacional do Estado quando ele viola direitos de estrangeiros em seu território. Celso de Albuquerque MELLO, op. cit. (nota 3), p.628.

${ }^{35} \mathrm{O}$ Tribunal de Nuremberg é um exemplo marcante. Mesmo que se reconheça que se tratou de um tribunal singular e de exceção, o que fere os princípios da anterioridade e da segurança jurídica, além de se constatar outras imperfeições jurídicas, é inegável que tal corte considerou o homem como sujeito do DIP.

${ }^{36}$ O Tribunal, criado em 1998 por 139 Estados, prevê em seu Estatuto que é dispensável que um indivíduo, para ser julgado, seja cidadão de um país signatário. Cf. artigos $1^{\circ}$ e 12 . Constata-se, portanto, a possibilidade de o homem ter deveres diretamente impostos pelo DIP, independentemente de seu Estado patrial ou de residência, ao contrário do que afirma José Francisco REZEK, op. cit. (nota 11) p.160. 
deveria possuir a prerrogativa de reclamar, nos foros internacionais, a garantia de seus direitos, e essa qualidade precisaria resultar de norma geral.

Para Marco Aurélio Antas Torronteguy, pode-se distinguir entre sujeitos diretos e indiretos do DIP. Aqueles possuiriam direito, pretensão e ação, enquanto estes deteriam somente direito e pretensão. ${ }^{37} \mathrm{O}$ indivíduo se enquadraria nesta última categoria, já que não pode demandar internacionalmente, devendo, em geral, ser representado por um Estado. Segundo o autor, portanto, o homem pode - e deve, em uma ótica democrática - ser considerado sujeito do direito internacional público, se admitido como indireto e fragmentário, dada a força que ainda detêm os Estados, mesmo em face das organizações e cortes internacionais. ${ }^{38}$

No mesmo sentido, Deisy Ventura e Ricardo Seitenfus, reconhecendo que a capacidade de agir é elemento determinante da personalidade jurídica, classificam o indivíduo como sujeito incapaz no âmbito internacional. ${ }^{39} \mathrm{Da}$ incapacidade decorre a representação internacional, que se verifica quando a manifestação de vontade de determinado sujeito produz efeitos que são imputados a outro. ${ }^{40}$

A limitada capacidade internacional do indivíduo não lhe retira, no entanto, o status de pessoa jurídica. A tutela internacional dos direitos do homem e a possibilidade de se lhe imputarem fatos ilícitos são elementos que ensejam sua consideração como sujeito do DIP, embora não pleno. A ausência ou os limites das demais capacidades, inclusive, demonstra o caminho, plenamente possível, a ser percorrido para a completa qualificação da personalidade jurídica internacional do indivíduo. Verificar as condições em que a pessoa humana é tratada por algumas das principais cortes internacionais parece ser fundamental nesse sentido.

\subsection{As possibilidades de acesso aos tribunais internacionais}

No início do século XX, a recém-criada Corte de Justiça Centro-americana (1907-1918) e os Tribunais Arbitrais Mistos do pós-Primeira Guerra Mundial

${ }^{37} \mathrm{O}$ autor baseia-se na teoria de Pontes de Miranda, para quem de todo direito decorre uma pretensão, que constitui a "posição subjetiva de poder exigir de outrem alguma prestação positiva ou negativa". A ação, por sua vez, seria a forma de exercício da pretensão. O indivíduo é sujeito de DIP? Inédito mimeografado. p.5.

38 Ibid., p.10.

${ }^{39}$ Op. cit. (nota 12), p.114.

${ }^{40}$ Celso de Albuquerque MELLO, op. cit. (nota 3), p.281. 
chegaram a admitir o indivíduo como litigante. O mesmo aconteceu, conforme já mencionado, nos Tribunais de Tóquio e Nuremberg, que julgaram os acusados da Segunda Grande Guerra. Contemporaneamente, o principal tribunal mundial, a Corte Internacional de Justiça, não admite o homem como parte em um litígio sob sua análise. Ele tampouco pode solicitar pareceres consultivos, a exemplo das organizações internacionais. Os julgamentos no âmbito da ClJ somente ocorrem, portanto, em demandas entre Estados. ${ }^{41}$

O Tribunal Penal Internacional, por sua vez, trata o indivíduo como sujeito de deveres internacionais, na medida em que admite sua presença no pólo passivo da relação processual penal, mesmo que seu país não seja signatário do Estatuto do Tribunal. Ele não pode, no entanto, formular denúncias, o que constitui competência exclusiva de um Estado-Parte, do Conselho de Segurança da ONU e do Procurador. ${ }^{42}$

No âmbito do Mercosul, os particulares continuam tendo uma participação restrita no sistema de solução de controvérsias. Eles são admitidos somente na condição de denunciantes, não de litigantes. A condição para acionar o procedimento arbitral é a aceitação do Estado-Parte onde residem habitualmente ou tenham a sede de seus negócios. ${ }^{43}$ Ocorre que tal fato não se constata freqüentemente. Muitas vezes os Estados não concordam com as reclamações dos particulares, não as submetendo, logo, ao sistema de solução de controvérsias do Mercosul. Isso pode acontecer porque essa decisão

não é jurídica, mas de mérito administrativo, revelando a característica do Mercosul de ser um processo de integração dos quatro Poderes Executivos, excluindo os Legislativos e Judiciários. $^{44}$

Na União Européia, processo de integração regional supranacional dotado de um direito próprio, essa realidade é diversa da maioria das instituições

\footnotetext{
${ }^{41}$ Artigos 92 a 96 da Carta da ONU e artigos 35 e 65 do Estatuto da Corte.

42 Artigo 13 do Estatuto do TPI.

${ }^{43}$ Artigos 39 a 44 do Protocolo de Olivos.
}

44 Marco Aurélio Antas TORRONTEGUY. Propuestas para un sistema permanente de solución de controversias en el MERCOSUR. In: Luiz Otávio PIMENTEL (Org.). Direito Internacional e da Integração. Florianópolis: Fundação Boiteux, 2003. p.874-875. Além da capacidade processual do indivíduo contra um Estado, o autor ressalta a necessidade de que dois particulares, do mesmo Estado ou não, atuem ao mesmo tempo como litigantes, e de que eles possam intervir na causa como terceiros interessados. p.875. 
jurisdicionais que são reguladas pelo direito internacional público clássico. Sob certas condições, o indivíduo dispõe de acesso aos foros de solução de controvérsias, nos quais é tratado em pé de igualdade com Estados e órgãos da própria UE.

O TJCE (Tribunal de Justiça das Comunidades Européias) é, assim, competente para resolver recursos interpostos por Estados-membros, instituições comunitárias e pessoas físicas ou jurídicas. ${ }^{45}$ Estas últimas poderão litigar relativamente a atos de que sejam destinatárias ou que the afetem direta e individualmente - o que demonstra a necessidade da presença de interesse jurídico -, além dos atos de regulamentação que the afetem diretamente e que não incluam medidas de execução. ${ }^{46}$

As ações cabíveis aos particulares são:

- Recurso de anulação, que controla a adequação ao direito comunitário dos atos e disposições emanados das instituições. Ressalte-se que os particulares somente podem manifestar-se quanto a atos administrativos em sentido estrito, não sobre disposições gerais;

- Recurso por omissão, que objetiva determinar que uma instituição pratique ato cuja omissão implica violação ao direito comunitário;

- Exceção de ilegalidade, que não se constitui em recurso autônomo, mas em alegação de ilegalidade de determinada norma comunitária no decurso de outro processo. Permite que particulares, não legitimados para tanto, possam recorrer de disposições gerais;

- Recurso por responsabilidade extracontratual da comunidade, que decorre de danos causados pelos órgãos ou agentes comunitários no exercício de suas funções.

O âmbito dos direitos humanos confere um espaço ainda maior ao indivíduo. O desenvolvimento desse ramo do direito internacional, sobretudo após a Segunda Guerra e com a criação da ONU, representou um verdadeiro salto de qualidade no DIP. Embora nem todos os Estados ofereçam o apoio necessário, a luta pela

\footnotetext{
${ }^{45}$ Artigo I, 28, 3 do Tratado que Estabelece uma Constituição para a Europa.

${ }^{46}$ Artigo III, 270, 4 do Tratado que Estabelece uma Constituição para a Europa.
} 
proteção internacional dos direitos humanos é significativa. Dentre suas principais conquistas, está o surgimento de diversos sistemas, jurisdicionais ou não, que procuram tutelar esses direitos.

$\mathrm{Na}$ esfera da ONU existe a Comissão de Direitos Humanos, que recebe e apura reclamações de indivíduos. Também o Pacto Internacional dos Direitos Civis e Políticos, de 1966, a Convenção Internacional sobre a Eliminação de Todas as Formas de Discriminação Racial, de 1965, e a Convenção contra a Tortura e Outros Tratamentos ou Penas Cruéis, Desumanos ou Degradantes, de 1984, estabelecem comitês para a proteção dos direitos que prescrevem ${ }^{47}$. Para uma reclamação de um indivíduo ou de um grupo de indivíduos ser enviada ao órgão, no entanto, o Estado deve reconhecer expressamente que reconhece a competência do comitê para tratar do assunto, mesmo já sendo signatário do acordo que a estabelece. No primeiro caso, tal reclamação apenas pode ser formulada por Estados, o que significa que o indivíduo deve ser representado, não tendo acesso direto ao comitê. Ademais, os documentos exigem que o órgão somente seja acionado quando esgotadas as possíveis vias internas de solução da questão.

$\mathrm{Na}$ Europa, o Acordo relativo a Pessoas que Participam nos Procedimentos da Corte Européia dos Direitos Humanos, assinado em Estrasburgo, em 1997, conferiu legitimidade à pessoa humana para litigar judicialmente contra Estados por violações aos direitos humanos definidos na Convenção Européia para a Proteção dos Direitos Humanos e das Liberdades Fundamentais, assinada em Roma, em 1950. A referida corte, portanto, é competente para julgar reclamações de pessoas singulares, ONGs ou grupos de particulares que se considerem vítimas de violação da Convenção. ${ }^{48}$

O Pacto de São José da Costa Rica (Convenção Americana sobre Direitos Humanos), assinado em 1969 pelos países latino-americanos, criou a Comissão e a Corte Interamericanas de Direitos Humanos no âmbito da OEA. O acesso direto do indivíduo somente ocorre na Comissão, perante a qual pessoas, grupos de pessoas ou organizações não-governamentais podem apresentar denúncias ou queixas

\footnotetext{
${ }^{47}$ Artigos $28-1$ a 45,8 a 16 e $17-1$ a 24 , respectivamente.

${ }^{48}$ Artigo 34.
} 
relativas à violação do Pacto, desde que esgotadas as vias internas. ${ }^{49}$ Apenas os Estados-Partes e a Comissão podem submeter um caso à Corte.$^{50}$ Existe, assim, a possibilidade de que a pretensão do indivíduo seja levada a julgamento mesmo que o Estado decida não endossar a questão.

\section{CONSIDERAÇÕES FINAIS}

Em um balanço das três faculdades básicas dos sujeitos de direito no âmbito internacional, tem-se que o Estado remanesce como o único ente a dispor de todas: capacidade jurídica, capacidade de agir e direito de participar da elaboração das normas. As organizações internacionais também as possuem, mas as duas últimas de forma incompleta. Seu poder de litigância é limitado, e a influência que possuem na concretização da normativa internacional parece, muitas vezes, ligar-se em demasia às vontades dos Estados que as conformam.

Ao indivíduo resta a relevante titularidade de direitos e obrigações, mas poucas oportunidades de pleitear judicialmente seus direitos - o que acontece sobretudo no plano europeu - e nenhuma participação na deliberação do direito criado internacionalmente. É, de fato, curioso que o homem não possa sequer reclamar a Declaração Universal dos Direitos do Homem perante a ClJ.

No entanto, mesmo com as restrições factuais e os condicionamentos legais que a norma internacional pode estabelecer, "na atualidade, é indiscutível haver clara atribuição da personalidade de direito internacional à pessoa humana" ${ }^{\text {"1 }}$. Esse entendimento parece adequado na medida em que não deixa de ser sujeito quem detém ao menos um viés da personalidade jurídica. Os próximos passos parecem residir, justamente, no sentido de aperfeiçoar essas capacidades.

Esse aperfeiçoamento, contudo, não deve necessariamente acontecer no modelo da personalidade jurídica estatal. Embora a personalidade jurídica internacional do homem, para ser plena, deva assimilar as capacidades dos Estados, é preciso e inevitável que se observem e se mantenham as particularidades desses entes tão diversos. Faz-se necessária uma adaptação das

\footnotetext{
${ }^{49}$ Artigo 44 do Pacto.

50 Artigo 61 do Pacto.

${ }^{51}$ Guido SOARES, op. cit. (nota 1), p.158.
} 
faculdades do sujeito tradicional do DIP à realidade do indivíduo. Por exemplo, soa como perfeitamente possível e pertinente que o homem possa acionar ampla e diretamente os tribunais internacionais em questões de seu interesse, notadamente no tocante aos direitos humanos. Por outro lado, a atuação do indivíduo nos fóruns internacionais e na elaboração de seu arcabouço jurídico demandará criatividade e inovação. Quiçá a participação de organizações não-governamentais possa suprir inclusive de maneira mais completa e comprometida, dada a sua especialidade - a participação da sociedade civil nesses processos legislativos.

Sob uma ótica humana, plural e solidária do direito internacional, não satisfaz a atual posição do indivíduo como sujeito incapaz. Ora, os incapazes no direito brasileiro são aqueles que realmente não têm condições de participar de modo pleno da vida jurídica. Isso não ocorre com a pessoa humana no DIP. O que há, ao contrário, é um monopólio interessado desse direito pelos Estados, não raras vezes somente pelo Poder Executivo.

Tal situação deriva, em parte, da sobrevalorização da Lei como fonte de direito, o que também se verifica no plano mundial. Se a norma é a principal referência conformadora do DIP, e se os indivíduos estão concretamente impossibilitados de lidar com ela, então eles não podem ser sujeitos plenos. Mas se o costume e a doutrina, além dos princípios gerais de direito, voltarem a possuir o peso que lhes é devido na realidade jurídica internacional, será forçoso considerar o homem como seu sujeito primordial.

Essas questões parecem inserir-se em uma necessidade mais abrangente a de uma revisão de certos preceitos tradicionais do DIP. Assim como outras áreas do direito, a seara internacional precisa acompanhar as mudanças sociais. Os ordenamentos jurídicos, destinados à regulamentação da vida em comunidade, tornam-se desnecessários quando se vêem obsoletos. É assim que se mostra o DIP quando ignora as possibilidades de atuação do indivíduo. Ademais, a tão clamada falta de legitimidade e de eficácia do direito internacional pode estar diretamente relacionada à forma como trata seus sujeitos e demais atores internacionais.

Uma vez que o homem é a finalidade última do direito, negar sua personalidade jurídica é desumanizar o direito internacional e afastá-lo das tendências de socialização e democratização. "A própria dignidade humana, que leva a ordem jurídica internacional a lhe reconhecer direitos fundamentais e procurar 
protegê-los, e a própria noção de Direito, obra do homem para o homem", ${ }^{52}$ levam a um inevitável reconhecimento dessa qualidade do indivíduo.

\section{REFERÊNCIAS}

ACCIOLY, Hildebrando. Manual de Direito Internacional Público. 11. ed. rev. São Paulo: Saraiva, 1978.

BONAVIDES, Paulo. Ciência Política. 10. ed. São Paulo: Malheiros, 1999.

GROTIUS, Hugo. O Direito da Guerra e da Paz. ljuí: UNIJUí, 2004. 2 v.

HIGGINS, Rosalyn. Problems \& Process: international law and how to use it. Oxford: Clarendon Press, 1994.

HOBSBAWM. Eric. A era dos extremos: o breve século XX (1914-1991). 2. ed. São Paulo: Companhia das Letras, 1998.

MELLO, Celso de Albuquerque. Curso de Direito Internacional Público. 9. ed. rev. e aum. Rio de Janeiro: Renovar, 1992.

MIRANDA, Pontes de. Tratado das Ações: ação, classificação e eficácia. v. 1. Campinas: Bookseller, 1998.

MONTEIRO, Washington de Barros. Manual de Direito Civil. v. 1. 5. ed. São Paulo: Saraiva, 1966.

PIMENTEL, Luiz Otávio (Org.). Direito Internacional e da Integração. Florianópolis: Fundação Boiteux, 2003.

PIMENTEL, Luiz Otávio et al. Solução de controvérsias: OMC, União Européia e MERCOSUL. Rio de Janeiro: Konrad Adenauer Stiftung, 2004.

REZEK, José Francisco. Direito Internacional Público: curso elementar 2. ed. São Paulo: Saraiva, 1991.

SEITENFUS, Ricardo. Manual das Organizações Internacionais. 3. ed. rev. e amp. Porto Alegre: Livraria do Advogado, 2003.

SEITENFUS, Ricardo. Textos fundamentais do Direito das Relações Internacionais. Porto Alegre: Livraria do Advogado, 2002.

SEITENFUS, Ricardo e VENTURA, Deisy. Introdução ao Direito Internacional Público. 3. ed. rev. e amp. Porto Alegre: Livraria do Advogado, 2003.

SILVA, José Afonso da. Curso de Direito Constitucional Positivo. 19. ed. rev. e atual. São Paulo: Malheiros, 2001.

\footnotetext{
52 Celso de Albuquerque MELLO, op. cit. (nota 3), p.624.
} 
SIMON, Denys. Le système juridique communautaire. 3. ed. Paris: Presses Universitaires de France, 2001.

SOARES, Guido. Curso de Direito Internacional Público. v. 1. São Paulo: Atlas, 2002.

VENTURA, Deisy. As assimetrias entre o MERCOSUL e a União Européia: os desafios de uma associação inter-regional. Barueri: Manole, 2003.

VIANA, Marco Aurélio S. Curso de Direito Civil: parte geral. v. 1.Belo Horizonte: Del Rey, 1993.

TORRONTEGUY, Marco Aurélio Antas. O indivíduo é sujeito de DIP? Inédito mimeografado. 